\title{
INDONESIAN RELATIVE CLAUSES AND ITS SIMILARITIES IN FOREIGN LANGUAGE
}

\author{
Rosmita Ambarita ${ }^{1}$, Mulyadi $^{2}$ \\ ${ }^{1}$ STIE SIBOLGA,Tapanuli Tengah \\ ${ }^{2}$ Universitas Sumatra Utara \\ ${ }^{1}$ rosa_ambar@yahoo.com, ${ }^{2}$ Mulyadi.usu@gmail.com
}

\begin{abstract}
This article discusses several points on the topic of Indonesian relative clauses and some foreign languages. The method used in this research is descriptive contrastive analysis. The focus is on finding some results from previous papers on how the languages share similarities and differences as well as how they differ with English. In this case it was found that Indonesian relative clauses are known as being distinctive and different from structured English counterparts. Meanwhile, there is a tendency that relative Indonesian clauses always use passive constructs to relate noun phrases or nouns in complex sentences.
\end{abstract}

Keywords: Relative Clauses, Foreign Language

\section{INTRODUCTION}

In traditional English books clauses are relatively the same as adjunctival clauses, for that reason relative clauses are related to qualifiers or modifiers of constituents consisting of nouns (Mallinson and B.J. Blake, 1981: 264). Nouns in that structure are the main words. Verhaar calls the main word the head of the main clause (Verhaar, 1981: 28). Furthermore Verhaar states that any relative clauses in the words agreed upon by a form of choreferentiality.

Example:

(1) Sheep that have long fleeces survive batter in winter.

'Domba yang berbulu panjang tahan hidup lebih baik dalam musim dingin.'

(2) Long-haired sheep survive batter in winter.

'Domba yang berbulu panjang tahan hidup lebih baik dalam musim dingin.'

Sentence (1) the constituents that have long fleeces are relative clauses, while (2) the longhaired constituents are adjectives. In sentence (3) the following can be paraphrased using the following relative clauses.

(3) Sheep that are long-haired survive batter in winter.

'Domba yang mempunyai bulu panjang tahan hidup lebih baik dalam musim dingin.'

Furthermore, Verhaar cites the opinion of Downing (1978) stating that relative clause markers include the presence of connective ligature. Verhaar asserted that on the basis of semantics, the main word must be choreferential with a relative clause or at least in the sense that the relative clause must be an attribute of the main word.

According to Bloomfield (1983: 188) the study of KR can be considered based on parathesis which is a diversity of parasintaxis that is as an element that interjects to other elements in complex sentences. Kridalaksana (1997: 111-112) provides a definition that KR in Indonesian is a bound clause Yang is preceded by a relative pronoun. As yang saya sukai in the following sentence: (1) Anak yang saya sukai terpilih. /The child I like is chosen. 
Meanwhile according to Biber (1999: 195) the English KR which is often also called the adjective clause is an explanatory noun phrase which usually begins with a relativizer or interrogative pronouns wh- (who, who, who, who, where, when, why). Khron gives a description of English relative clauses as well as in Indonesian is divided into two, namely the boundary Relative Clause (RC) Klausa Relatif (KR) and the bound RC, the explanation and explanation. The limiting RC gives identity to the noun words / phrases, its presence is obligatory because it is part of the clause in its entirety. (Djajasudarma, 1997: 34) XXB to Comrie $\mathrm{RC}$ the restrictive type is a clause which in this case serves as a limitation, therefore the information cannot be removed.

For example in the following sentence:

\section{1)The man that showed us the city is called Jhon karl}

'The person who showed us the city was known as Jhon Karl.

The relative clause that showed us the city tells which man he is referring to. Another case with nonrestrictive RC. In this type of clause information can be omitted or optional and only as an addition, in the sense that without any additional explanation the sentence is sufficiently clear. For example in following sentences:

\section{2)Fred, that showed us the city, is called Jhon Karl}

'Fred, the person who showed us the city, was known as John Karl'.

According to Comrie in sentence no (2) the listener is considered to already know who Fred is, while who showed us the city is just additional information. This additional sentence can be omitted because it is not restrictive, so this type of clause is often also called apositive, descriptive or explanatory. Comrie further explained that the restrictive of RC is orthographically written without being flanked by a comma while the nonrestrictive is flanked by a comma.

The division of RC that is in a restrained and non-restrictive type can be seen in the following example:

3) Bachtiar proposed the daughter of my uncle who has a long hair.

'Bachtiar meminang anak perempuan paman saya yang berambut panjang'.

In connection with the examples cited by Comrie and their equivalent in the Indonesian language, further requiring careful limitation and characterization because such problems are a challenge for the next researchers. In discussing relative clauses, it also relates to the issue of the position of clauses relative to their parent constituents. In this case Mallinson and Blake (1981: 261-371) as well as the Sixth and Comrie (1979) state that there is a strong correlation between the basic word order of the parent constituents and their relative clauses. Languages belonging to the type of VO (object-verb) of the parent constituents have a strong tendency to be ahead of their relative clauses, for example Acehnese, Batak and Cambodian languages.

There are at least eight relational strategies in many languages in the world. The eighth strategy has been proposed by Givon (1976: 147-151). Relative strategy data is taken from several languages. The eight strategies are as follows:

1) the nonreduction strategy

2) The non-reduction strategy is relativity with the emergence of nominal phrases that are relative in the relative clauses in full form, for example, in Hindi.

3) Aadmii ne jis caakuu se murgi ko.

SU men who knife with DO chicken

maaraa thaa us caakuu ko Raam ne dacha 


\section{The gap strategy}

This strategy is a way of relativity by dabbing nouns in relative clauses that are choreferential with their parent constituents without morphemic marks on 'relative verbs' (Verhaar's term 1981: 27), for example in Japanese

\section{5) Onna-ni tegemi-o kaita otoko-wa}

Woman-letter-writing man-topic

'Orang pria yang menulis surat kepada wanita itu.'

\section{The Word-Order Strategy}

This strategy occurs in the relativity of the subject or object directly by placing its position before or after the verb. Givon gives examples of relative clauses in English

6)The man saw susi

Articles- people ((men)- saw (in the past) susi

yesterday is a singer

yesterday- copula- article

$(\mathrm{NP}=$ Noun phrase $)-\mathrm{V}($ verb $)$ - NP)

7) The man, susi saw yesterday ia a singer

'Orang pria yang dilihat Susi kemarin adalah seorang penyanyi.'

(NP-NP-V ...)

(objek)

\section{The Nominalization Strategy}

This strategy is to make relative clauses a minimum, at least one argument that is characterized by genetical affixes and their relative verbs appear in nominal terms. The discussion in this article is a subordinate relationship that is limited to the expansion of one of its syntactic functions, namely the syntactic function of the subject, object, or description. This also applies to the structure of the German language. Limits of syntactic functions that will be described only on the structure of the function as Nominativ or subject, Accusative, Dativ or preposition object or phrase as a description of the place in the developed clause.

Consider the following example.

8) Saya bertemu paman yang memiliki rumah mewah.

I met uncle who has a luxury house

9) Paman yang memiliki rumah mewah itu meninggal kemarin.

The uncle who owned the luxury house died yesterday

The italics are embedded clauses or relative clauses. The clause that has a luxury home, is a relative clause that explains each of the syntactic functions in each sentence. This study cannot be separated from structural or grammatic studies in the language. Keenan and Comri are two linguists who have talked about the Relative Clause In the languages of the world including in Indonesian. Relative clauses in Indonesian can be seen in Keenan in the Language Typology and Syntactic description book edited by Timothy Shopen (1985) but Keenan only gives examples of Relative Clauses which are limited to the use of prepositions without adequate explanation. 
Then the discussion on Relative Clause can also be found in the book Universal Language and Linguistic Typology written by Comrie (1992) on pages 157-161 can be found in the use of Relative Clauses in Indonesian. Indonesia's contrastive study of the relative functions of the pronouns and the nature of the relative presence and words and the relativity strategies. Comri discusses the universality of Relative Clauses in several languages in the world. In Indonesian Comrie discusses how the relativity strategy. This topic was discussed earlier by Suharsono (2015) and Indira (2010) in different perspectives. The first author focuses on the study of the mistakes of Indonesian learners for Foreign Speakers (BIPA) in producing relative clauses and the second author focuses on relative clauses in German. This paper focuses on the comparison of relative clauses in several foreign languages.

\section{METHOD}

This research uses descriptive and comparative methods. Initially relative clauses will be described in Indonesian and several foreign languages. In the Indonesian description relative clauses will be broken down based on their syntactic functions, substitute subjects, substitute objects, and substitute information. Likewise in German. Relative clauses will be described relative to Nominative, Accusative, Dativ, and place information. After describing, the relative sentences of each sentence will be seen. These characteristics will be described and analyzed based on the substitute word, place, composition and structure. These characteristics will eventually be compared and it will be concluded that similarities and differences in relative clauses between Indonesian and several foreign languages.

\section{RESULTS AND DISCUSSION}

\section{Results}

Leech (1975: 285) states that the English KR can be used for various types of sub-clauses which are connected to some or all of the main clauses by a rear pointer, usually a relative pronoun. The main principle of KR is to explain noun phrases where the relative pronouns refer back to the noun phrases. Leech further explained that the English KR always begins with the use of relative pronouns that differ according to the type of noun that he refers to. Relative pronouns who are used to explain human nouns that are functioning as subjects, whom are used to describe human nouns that are functioning as objects, whose are used to explain ownership, and which are used to describe non-human nouns that are functioning both as subjects and as objects , while that can be used to explain all types in various functions. The type of gender does not affect the relative form of pronouns. The relative meanings of pronouns where, when, and why will not be discussed given the limitations of space and time. In detail the formation of KR in each language is as follows.

1. Describe the Subject

(1) The man who is handsome sang a song.

'Lelaki yang ganteng itu telah menyanyikan sebuah lagu'

(2)The man whom I love sang a song.

'Lelaki yang saya cintai itu telah menyanyikan sebuah lagu

(3) The man whose book I borrowed sang a song.

'Lelaki yang bukunya saya pinjam telah menyanyikan sebuah lagu.

(4) The man that is handsome sang a song.

'Lelaki yang ganteng itu telah membaca sebuah buku.' 
The sentences (1-4) show the relative pronouns who are used to explain the subject, whom is used to explain the object and whose to express their own, while that is used to replace who, who, and whose.

2. Describe the Subject of Tan Beings

(5) The book which is green lies on the table

'Buku yang hijau itu terletak di atas meja itu.'

(6) The book which I bought yesterday lies on the table

'Buku yang saya beli kemarin terletak di atas meja itu.'

(7) The book which cover is green lies on the table

'Buku yang sampulnya biru terletak di atas meja itu.'

(8) The book that is green lies on the table

'Buku yang bagus itu terletak di atas meja itu.'

In contrast to the sentences (1-4) the sentences in example (5-7) show the relative pronouns for the nouns but creatures remain the same even though they explain subject, object, and ownership. While sentence (8) shows that that can be used for nouns and creatures.

3 Describe the Object

(9) I love a man who is handsome.

'Saya mencintai seorang lelaki yang tampan.'

(10) I love a man whom I know.

'Saya mencintai seorang lelaki yang saya kenal.'

(11) I love a man whose book is good.

'Saya mencintai seorang lelaki yang bukunya bagus.'

Sentence (9-10) shows that KR in English has the same form both in explaining the subject and the object consisting of nouns.

4. Explanation of Tan Creature Objects

(12) I have a book which is good

'Saya punya sebuah buku yang bagus.'

(13) I have a book which I read

'Saya punya sebuah buku yang telah saya baca.'

(14) I have a book which cover is blue.

Saya punya sebuah buku yang jilidnya berwarna biru.'

The sentences in example (12-14) also show that RC has the same form both in explaining the subject and the object for the noun being. The formation of RC in German is slightly different from the formation of English RC because German does not differentiate the creature noun from the creature and emphasizes feminine, masculine and neutral nouns, as shown in the following sentence.

(15) Der Mann, der gut aussah, schreib ein Buch.

The man who is handsome wrote a book. 
'Lelaki yang ganteng itu telah membaca sebuah buku.'

(16) Der Mann, den ich libie, schreibt ein Buch.

The man whom I love wrote a book.

'Lelaki yang saya cintai itu telah membaca sebuah buku.'

(17) Der Mann, dessen Buch ich koufte, schreib ein Buch.

The man whose book I bought wrote a book.

Lelaki itu yang bukunya telah saya beli telah membaca sebuah buku

(18) Das Buch, das gut ist, liegt aufdem Tisch.

The book which is good lies on the table

'Buku yang bagus itu terletak di atas meja itu'.

(19) Das Buch, den ich liebe, liegt auf dem Tisch.

The book which I bought yesterday lies on the table

'Buku yang saya beli kemarin terletak di atas meja itu.'

(20) Das Buch, dessen bundeblau ist, liegt aufdem Tisch

The book which cover is blue lies on the table

'Buku yang jilidnya biru itu terletak di atas meja itu.'

The sentence in the example above shows that the relative German pronoun has the same sex and number as the words it represents and is determined by its function in the sentence as for the subject (der, die, das), for dative (dem, der, dem), for genitive (dessen, deren, dessen) and for accusative (den, die, das).

\section{The Process of contrastive Analysis}

The process of contrastive analysis work is comparing aspects of language in two languages. Halliday (1970) states that there are two principles in contrastive analysis. First is the examination stage. The examination stage is the observation stage, the description of a case in a particular language. The second stage is comparing certain patterns or certain aspects in a language and not comparing as a whole In the first principle expressed or described how the language works and focus on aspects to be compared. Next, a description of the aspects or focus of the language to be compared is performed That is, if described two aspects or two focus of the language part of the two languages certainly understanding the two languages is needed.In the second principle, it is stated that what is compared is only one aspect or focus of language. It cannot be compared to two languages as a whole. In the context of this paper, aspects of relative clauses in Indonesian and German will be discussed. Because typologies and linguistic properties differ even in the relative focus of clauses, not all parts of relative clauses can be compared. Therefore, the findings of this paper certainly produce aspects of similarities and aspects of differences that can be revealed.Based on the description of the information of relative clauses in Indonesian and German can be seen some similarities and some differences. The equation is based on its location, the relative clause is to the right of the main clause. This is very logical because relative clauses describe one of the syntactic functions of complex sentences so that the explanation follows what is explained. Next, the relative clause attaches directly to the relative noun. In German, the spelling between commas is different from Indonesian. In the Indonesian language, which is marked between commas is an additional position or information. German relative verb clauses must be at the end of a subordinate clause. 
This is related to the stratified compound sentence structure rules in German. In Indonesian, the pronoun is usually followed by a predicate.

Based on the data described there is a syntactic function equation that is relative which is Nominative in German equivalent to Subject, Akkusativ and Dativ are equivalent to objects, Dativ in German is equivalent to ownership. There is a similar process in the context of the absorption of nouns because they have been defined with relative corresponding pronouns. The difference is that most of the relative pronouns that relatize the nouns of subjects and objects always use those in Indonesian and use the relative pronouns according to the case and genus in German.

\section{CONCLUSION}

Based on the explanation and examples that have been stated, it is concluded that Relative Clauses (RC) is an element that interjects to other elements in complex sentences. Such relative clauses can be found in English and German. Among these three languages the Relative Clauses of English is more complex and varied because it distinguishes between the form of the subject, object and ownership as well as the existence of obligatory and optional RC. The obligatory one does not require punctuation which is the opposite of the optional character which is always between commas. Also in English RC distinguishes the form of explanation for human nouns from non-human nouns. While German only knows one Relative Clauses which is obligatory and always exists between commas. The difference lies in the type of object that is referred to whether including masculine, feminine or neutral nouns in addition to considering the use of nominative, accusative, dative, and genitive. In simple relative pronouns in Indonesian are represented by which while in German can be a variety of pronouns.

\section{ACKNOWLEDGMENTS}

Alhamdulillah thanks to Allah the Almighty the author can complete this article.

The aims of writing this article to fulfil the assignment of typology Subject in Linguistic program Faculty of cultural science University of Sumatra Utara.

In completed this article the author supported by special some special people and would like to dedicate special thanks to:

1. Dr.Eddy Setia,M.Ed,TESP as the Head of S-3 Linguistic Study Program Faculty of cultural science University of Sumatra Utara

2. Dr.Mulyadi,M.Hum as the lecturer and secretary of S-3 Linguistic Study program of Faculty Cultural Science University of Sumatra Utara.

3. Drs.Kaharuddin Simamora,SE,MA,MM that always support the author at any time as husband and partner in process of Study.Last hopefully this article can be useful for the readers.

\section{REFERENCES}

Arifin, S. (1990). Tipe-tipe klausa bahasa Jawa. Departemen Pendidikan dan Kebudayaan.

Bernard, C. (1981). Relative clauses. Language universals and linguistic typology. Syntax and morphology, Oxford, Basil Blackwell Publisher, 138-164.

Comrie, B. (2003). The verb-marking relative clause strategy, with special reference to Austronesian languages. Linguistik Indonesia, 21, 1-18.

Jacobs, R. A., \& Rosenbaum, P. S. (1969). English transformational grammar. 
Klamer, M. A. F. (2002). Typical features of Austronesian languages in central/eastern Indonesia. Oceanic Linguistics, 41(2), 363-383.

Kridalaksana, H. (2002). Struktur, kategori, dan fungsi dalam teori sintaksis. Universitas Katolik Indonesia Atma Jaya.

Parera, J. D. (1991). Kajian linguistik umum historis komparatif dan tipologi struktural. Erlangga.

Purwo, B. K. (2000). Bangkitnya kebhinekaan dunia linguistik dan pendidikan. Mega Media Abadi.

Van den Berg-Klingeman, L. (1986). Klausa relatif bahasa Indonesia dan bahasa Muna. Panitia Bulan Bahasa Universitas Hasanuddin. 